\title{
Bronchial brush biopsies for studies of epithelial inflammation in stable asthma and nonobstructive chronic bronchitis
}

\author{
G.C. Riise*, B. Andersson**, S. Ahlstedt+, I. Enander ${ }^{+}$, \\ M. Söderberg++, O. Löwhagen\#, S. Larsson*
}

Bronchial brush biopsies for studies of epithelial inflammation in stable asthma and nonobstructive chronic bronchitis. G.C. Riise, B. Andersson, S. Ahlstedt, I. Enander, M. Söderberg, O. Löwhagen, S. Larsson. CERS Journals Ltd 1996.

ABSTRACT: Recently, bronchial brush biopsy (BBB) has been introduced as a complimentary method to bronchial forceps biopsy for the study of bronchial epithelial cells. We wanted to determine whether epithelial inflammatory cells in bronchial brush biopsies can reflect mucosal inflammation assessed indirectly by levels of cellular activation markers in bronchial lavage fluid.

We studied 15 healthy controls, 11 asthmatics with regular steroid inhalation therapy, 13 asthmatics without steroids, and 10 smokers with nonobstructive chronic bronchitis. Differential counts of epithelial and inflammatory cells were made from the BBB material. Bronchial lavage levels of eosinophil cationic protein (ECP), myeloperoxidase (MPO), tryptase, hyaluronan and interleukin-8 (IL-8) were measured as indirect markers for inflammatory cell activation.

We found an increased percentage of eosinophil granulocytes in the BBB from the steroid-untreated asthmatic patients $(\mathbf{1 . 1 6 \%})$ in comparison to the other groups $(0.11 \%, 0.09 \%$ and $0.02 \%$, respectively; $\mathbf{p}<0.01)$. In the steroid-untreated asthmatic patients, the percentage of eosinophils correlated with ECP in bronchial lavage fluid $(r=0.73 ; p<0.01)$, indicating that the BBB method can reflect the degree of eosinophilic activation. A negative correlation was found for the percentage of eosinophils in BBB with levels of provocative concentration of methacholine causing a $20 \%$ fall in forced expiratory volume in one second $(\mathrm{PC} 20)$ for the asthmatic patients in the study $(r=-0.67 ; p<0.003)$.

The bronchial brush biopsy method appears to give information on the changes present in superficial bronchial epithelium in inflammatory airways disease. These changes appear to relate to the degree of inflammatory activity and disease severity in asthma.

Eur Respir J., 1996, 9, 1665-1671.
*Dept of Pulmonary Medicine and \#Dept of Allergy, Sahlgrenska University Hospital, Göteborg, Sweden. **Dept of Clinical Immunology, University of Göteborg, Göteborg, Sweden. +Pharmacia Diagnostics AB, Uppsala, Sweden. ++Dept of Pulmonary Medicine, Umeå Hospital, Umeå, Sweden.

Correspondence: G.C. Riise Dept of Pulmonary Medicine Br. Str. 11

Sahlgrenska University Hospital S-413 45 Gothenburg Sweden

Keywords: Airway inflammation asthma

brush biopsy

chronic bronchitis

cytology

Received: February 221995

Accepted after revision January 141996
The flexible fibreoptic bronchoscope has proved to be a useful research tool in investigating inflammatory airway diseases. Recently, bronchial brush biopsy (BBB) has been introduced as a complimentary method to bronchial forceps biopsy for the study of bronchial epithelial cells both morphologically $[1,2]$ and functionally $[3,4]$. The method gives information specific to the superficial airway epithelium, since principally cells above the basement membrane are collected. The cytological outcome for the BBB method is dominated by $>90 \%$ epithelial cells, but inflammatory cells have also been demonstrated $[1,2]$.

In asthma, biopsies obtained using bronchial forceps have shown the mucosal airway changes to consist of a predominance of eosinophil and mast cell infiltration [5-9]. Specific molecules from activated inflammatory cells have been detected in BAL from asthmatic patients, including eosinophil cationic protein (ECP) from eosinophil granulocytes [10], tryptase from mast cells [11], and free hyaluronan from fibroblasts [12]. Regular treatment with inhaled steroids has been shown to ameliorate the airway inflammation in asthma [13-15].

The airway inflammation in chronic bronchitis has not been as well characterized as that in bronchial asthma. Histopathological studies of large airway mucosa in patients with chronic bronchitis have demonstrated infiltration of mononuclear phagocytes [16], lymphocyte infiltration and lymphocyte activation [17]. BAL and bronchial lavage fluids have shown elevated numbers of macrophages and neutrophil granulocytes [18, 19], as well as increased levels of myeloperoxidase (MPO) [20].

We attempted to investigate the usefulness of the BBB method in characterizing the bronchial epithelial inflammation in three groups of well-defined patients: asthmatics with and without inhaled steroid therapy, and patients with nonobstructive chronic bronchitis. We wanted to determine whether accumulation of epithelial inflammatory cells in bronchial brush biopsies can reflect intrabronchial mucosal inflammation assessed indirectly by levels of activation markers for airway inflammatory cells. 


\section{Materials and methods}

\section{Design}

Flexible fibreoptic bronchoscopy was performed, and standardized bronchial brush biopsies as well as small volume $(20 \mathrm{~mL})$ lavage of the large airways were obtained. Differential counts of epithelial cells, eosinophil granulocytes (Eos), polymorphonuclear granulocytes (PMN), macrophages and mononuclear cells were made from the BBB material. Bronchial lavage fluid and serum levels of ECP, MPO, tryptase and hyaluronan were used as indirect markers for activation of eosinophils, neutrophils, mast cells and fibroblasts, respectively. Interleukin-8 (IL8) was measured as a marker for chemotactic attraction and activation of neutrophils.

Atopy was defined as a history of upper or lower airway symptoms to common aeroallergens verified by positive skin prick test (birch tree, grass and mugwort pollen, dog and cat epidermis, Aspergillus fumigatus, Dermatophagoides pteronyssinus) or by radioallergosorbent test for specific immunoglobulin E (IgE) (Phadiatop®; Pharmacia, Uppsala, Sweden). All bronchoscopies were performed out of the pollen allergic season and by the same experienced bronchoscopist (GCR).

\section{Subjects}

Group 1. Fifteen healthy controls (14 lifelong nonsmoking volunteers and one ex-smoker since $20 \mathrm{yrs}$ ). All had normal spirometry, negative methacholine test (provocative concentration causing $>20 \%$ fall from baseline forced expiratory volume in one second (FEV1) (PC20 $>16 \mathrm{mg} \cdot \mathrm{mL}^{-1}$ ), and no signs of infectious respiratory disease during the previous 4 weeks. Four of these subjects were atopic.

Group 2. Twenty four patients with bronchial asthma defined according to the criteria of the American Thoracic Society (ATS) [21]. They all had positive methacholine challenge test $\left(\mathrm{PC} 20<4 \mathrm{mg} \cdot \mathrm{mL}^{-1}\right)$, or an increase in FEV1 of $>20 \%$ on $\beta_{2}$-agonist inhalation. All were lifelong nonsmokers (except for one ex-smoker), with no signs of infectious respiratory disease or obstructive symptoms during the previous 4 weeks. These patients were divided into two subgroups.
Group $2 a$. Thirteen patients with mild asthma requiring symptomatic therapy with inhaled $\beta_{2}$-agonists only occasionally. None used inhaled or oral steroid medication, nor other oral antiasthma medication. Nine of these subjects were atopic.

Group $2 b$. Eleven patients with bronchial asthma and on a regular medication with inhaled steroids administered by powder inhaler devices for more than $1 \mathrm{yr}$ (mean 836 $\mu \mathrm{g}$ beclomethasone or budesonide per day), together with inhaled $\beta_{2}$-agonist medication as required. Seven of these subjects were atopic.

Group 3. Ten patients with nonobstructive chronic bronchitis. All were current smokers (mean 34 pack-years) with productive daily cough for at least three consecutive months each year during the past 2 yrs, and they had normal spirometry (table 1). Methacholine tests were negative (PC20 >16 mg. $\mathrm{mL}^{-1}$ ), and no increase was seen in FEV 1 on $\beta_{2}$-agonist inhalation. None had a history of recurrent infective exacerbations. Three of these subjects were atopic. For further patient data see table 1.

Of the 24 asthmatic patients, four used oral $\beta_{2}$-agonists regularly, and one used oral theophylline preparations (all in Group 2b). Of the 10 patients with chronic bronchitis, one used ipratropium bromide for inhalation as required, the others used no airway medication.

The duration of the respiratory symptoms varied for the asthmatics between 3 to 30 yrs (mean 9 yrs), and for the bronchitics between 2 to 20 yrs (mean $8.5 \mathrm{yrs}$ ). Ventilatory lung function (FEV1) was measured with a Bernstein spirometer or a Vitalograph. All methacholine provocation tests were performed within 4 weeks prior to the bronchoscopy.

Criteria for exclusion were: abnormal chest radiograph; bronchial hypersecretion caused by factors other than cigarette smoking for the bronchitis patients; age $>65$ yrs; and, for safety reasons, a methacholine test of $<0.5$ $\mathrm{mg} \cdot \mathrm{mL}^{-1}$ in the steroid untreated asthmatic patients (Group 2a). The study design was approved by the Ethics Committee of the University of Göteborg, and all subjects gave their consent after both written and oral information.

\section{Fibreoptic bronchoscopy}

Premedication was given with diazepam $5 \mathrm{mg}$ orally, followed by $0.5-1 \mathrm{~mL}$ morphine-scopolamine i.m. For

Table 1. - Clinical details of subjects: gender, number of subjects with atopy, age, FEV1 and level of positive methacholine provocation test ( $\left.\mathrm{PC}_{20}\right)$

\begin{tabular}{|c|c|c|c|c|c|c|}
\hline \multicolumn{2}{|c|}{ Group } & \multirow{2}{*}{$\begin{array}{l}\text { Sex } \\
\text { M/F } \\
4 / 11\end{array}$} & \multirow{2}{*}{$\begin{array}{c}\text { Atopy } \\
\text { n }\end{array}$} & \multirow{2}{*}{$\begin{array}{c}\begin{array}{c}\text { Age } \\
\text { yrs }\end{array} \\
39(20-62)\end{array}$} & $\begin{array}{l}\text { FEV1 } \\
\% \text { pred }\end{array}$ & \multirow{2}{*}{$\begin{array}{c}\begin{array}{c}\mathrm{PC} 20^{\#} \\
\mathrm{mg} \cdot \mathrm{mL}^{-1}\end{array} \\
>16.0\end{array}$} \\
\hline 1. & Healthy controls $(n=15)$ & & & & $106(130-85)$ & \\
\hline $2 \mathrm{a}$. & $\begin{array}{l}\text { Asthma without } \\
\text { inhaled steroids }(n=13)\end{array}$ & $3 / 10$ & 9 & $40(22-62)$ & $92(80-103)$ & $0.75(0.5-2.0)$ \\
\hline $2 b$. & $\begin{array}{l}\text { Asthma with } \\
\text { inhaled steroids }(n=11)\end{array}$ & $7 / 4$ & 7 & $47(22-63)$ & $93(83-101)$ & $4.00(2.0-8.0)$ \\
\hline 3. & Chronic bronchitis $(n=10)$ & $4 / 6$ & 3 & $45(31-62)$ & $100(83-113)$ & $>16.0$ \\
\hline
\end{tabular}

Values are presented as mean, and range in parenthesis. \#: geometric mean. M: male; F: female; FEV1: forced expiratory volume in one second; PC20: provocative concentration of methacholine causing a $20 \%$ fall in FEV1; $\%$ pred: percentage of predicted normal. 
topical anaesthesia, $1 \%$ preservative-free tetracaine was sprayed with a Devilbiss nebulizer in the larynx, and additional anaesthesia was applied through the bronchoscope channel for the lower respiratory tract. Bronchoscopy was performed transorally, and various models of Olympus flexible fibreoptic bronchoscopes were used. Throughout the procedure, all subjects in the study, including the healthy controls, received continuous i.v. infusion of terbutaline at $2.5 \mu \mathrm{g} \cdot \mathrm{min}^{-1}$. Supplemental $100 \%$ oxygen was delivered nasally at 2-3 L. $\mathrm{min}^{-1}$, and blood oxygen saturation was monitored with an Ohmeda pulse oximeter (Ohmeda, Louisville, KY, USA). Seven asthmatic patients, all from the group without regular steroid medication (Group 2a), developed mild obstruction during the latter part of the bronchoscopy. Only one of these required additional bronchodilator therapy for the symptoms to recede. None developed a late asthmatic reaction after the investigation.

\section{Collection of samples}

All samples were collected between 8.30 and 10 a.m. Serum was separated from the $10 \mathrm{~mL}$ venous blood sample according to AHLSTEDT et al. [22], and frozen at $-20^{\circ} \mathrm{C}$ for later analysis of ECP, MPO, IL-8, hyaluronan and tryptase.

Bronchial lavage fluid was obtained by a single instillation of $20 \mathrm{~mL}$ sterile phosphate-buffered saline (PBS), with the bronchoscope in an unwedged position in the anterior segment of the right upper lobe. The fluid was immediately aspirated, collected in a sterile container and transported on ice to the laboratory, where the cells were sedimented by centrifugation and the supernatant frozen at $-20^{\circ} \mathrm{C}$ for later analysis of inflammatory markers.

Standardized bronchial brush biopsies were then taken with a sterile single-sheathed nylon cytology brush (Olympus BC 9C-26101) as described previously [1]. In brief, three consecutive brushings from an approximately 3-4 $\mathrm{cm}^{2}$ intrabronchial area were taken from the proximal part of the right main bronchus. The brush was agitated in a vortex in $1 \mathrm{~mL} 0.9 \%$ saline between each brushing, and cytocentrifuge slides (Shandon Southern Products Ltd, Runcorn, UK) were then made from $100 \mu \mathrm{L}$ aliquots of the pooled brush samples. Slides were immediately fixed in 96\% alcohol and then stained with May-Grünwald Giemsa for later identification of cell types on a morphological basis. Percentages of epithelial cells, eosinophil granulocytes, polymorphonuclear granulocytes, macrophages and mononuclear cells were calculated by counting 1,000 cells using a standard light microscope at $\times 100$ magnification. The term "mononuclear cells" was used, since no further differentiation between lymphocytes and monocytes was attempted. All samples were analysed in a blinded manner.

\section{Analysis of inflammatory markers}

Kits for analysis of ECP [23], MPO [24], hyaluronan [25] and tryptase [26] (Pharmacia Diagnostics AB, Uppsala, Sweden) were used according to the instructions of the manufacturers.
IL-8 was analysed using a modified sandwich fluorescent enzyme immunoassay method (Pharmacia Diagnostics AB, Uppsala, Sweden). Briefly, the bronchial lavage fluid was incubated in microtitre wells coated with a mouse monoclonal antibody against IL-8. All samples were diluted in the standard dilution buffer. After washing, a goat anti-IL- $8 \beta$-galactosidase-conjugate was added and the plates were incubated. The response was measured fluorometrically. Recombinant IL-8 [27] was used as standard ranging $10-2,000 \mathrm{ng} \cdot \mathrm{L}^{-1}$. The intra- and interassay coefficients of variation were less than $10 \%$ and the detection limit was $5 \mathrm{ng} \cdot \mathrm{L}^{-1}$.

\section{Statistical evaluation}

The inflammatory cell counts are expressed as arithmetic mean and standard deviations (SD). The levels of soluble markers are presented as median and SEM. Nonparametric statistical analysis was used throughout the study since each subject group was small, and the data were without normal distribution. Kruskall-Wallis test was used to analyse the significance of differences in numerical data between the four groups of subjects. Mann-Whitney U-test was used for the comparison of the distribution of inflammatory markers and bronchial epithelial cells between subgroups of subjects. Spearman's rank correlation test was used to examine possible associations between markers, cells and clinical parameters.

\section{Results}

\section{Inflammatory cells in bronchial brush biopsies}

The percentage of eosinophil granulocytes was significantly higher in the steroid-untreated asthmatic patients (Group 2a) $(p<0.01)$ than in the controls (fig. 1). In contrast, the percentage of epithelial cells, neutrophils, macrophages and mononuclear cells did not differ between the groups (table 2).

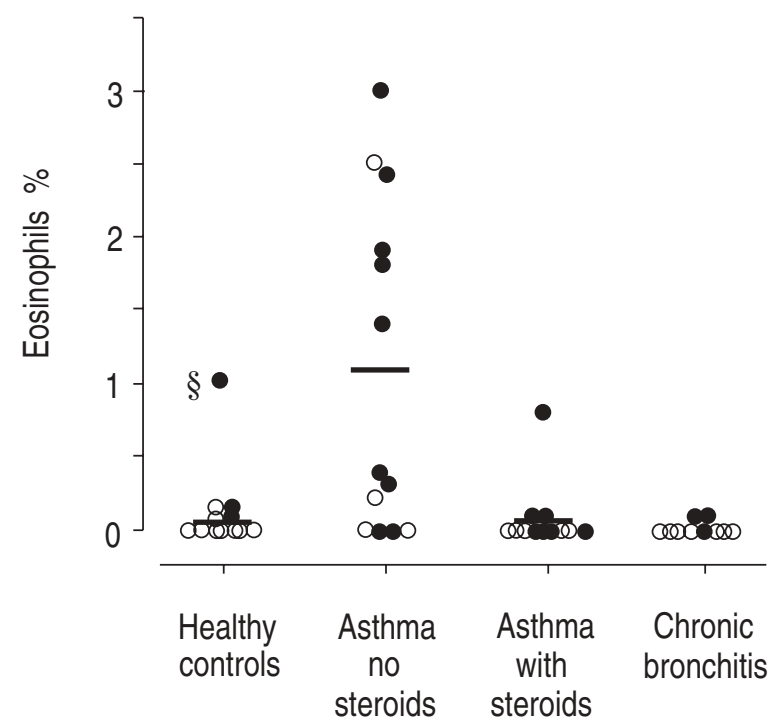

Fig. 1. - Percentage of eosinophils in bronchial brush biopsies in patients and healthy controls. Subjects with atopy are indicated by filled circles. Bold lines represent mean values. §: atopic control, who developed asthma $1 \mathrm{yr}$ after the study. 
Table 2. - Different counts of cells in the bronchial brush biopsies

\begin{tabular}{|c|c|c|c|c|c|c|c|}
\hline \multicolumn{2}{|c|}{ Group } & \multirow{2}{*}{$\begin{array}{c}\begin{array}{c}\text { Epi } \\
\%\end{array} \\
91.2(1.1)\end{array}$} & \multirow{2}{*}{$\begin{array}{c}\begin{array}{c}\text { Eos } \\
\%\end{array} \\
0.11(0.07)\end{array}$} & \multirow{2}{*}{$\begin{array}{c}\text { PMN } \\
\%\end{array}$} & \multirow{2}{*}{$\begin{array}{c}\begin{array}{c}\mathrm{Mac} \\
\%\end{array} \\
0.97(1.2)\end{array}$} & \multirow{2}{*}{$\begin{array}{c}\begin{array}{c}\text { Mono } \\
\%\end{array} \\
0.99(0.2)\end{array}$} & \multirow{2}{*}{$\begin{array}{c}\text { Others } \\
\%\end{array}$} \\
\hline 1. & Healthy controls & & & & & & \\
\hline $2 \mathrm{a}$. & $\begin{array}{l}\text { Asthma without } \\
\text { inhaled steroids }\end{array}$ & $91.3(1.0)$ & $1.16(0.3)^{* *}$ & $1.52(0.7)$ & $0.36(0.4)$ & $1.67(0.1)$ & $4.00(0.3)$ \\
\hline $2 b$. & $\begin{array}{l}\text { Asthma with } \\
\text { inhaled steroids }\end{array}$ & $92.4(1.9)$ & $0.09(0.07)$ & $2.43(1.7)$ & $0.25(0.2)$ & $1.01(0.1)$ & $3.76(0.5)$ \\
\hline 3. & Chronic bronchitis & $91.4(1.9)$ & $0.02(0.01)$ & $2.13(1.2)$ & $0.27(0.5)$ & $1.52(0.3)$ & $4.57(0.5)$ \\
\hline
\end{tabular}

Values are presented as mean and SEM in parenthesis. Epi: epithelial cells; Eos: eosinophils; PMN: polymononuclear granulocytes; Mac: macrophages; Mono: mononuclear cells. **: $\mathrm{p}<0.01$ versus the controls (Mann-Whitney U-test).

The percentage of ciliated epithelial cells for all subjects were $58 \%$ (SEM 2\%), goblet cells $10 \%$ (SEM 2\%), and basal cells (including epithelial cells of uncertain morphology) $32 \%$ (SEM 1\%). No differences were found between the groups.

The 23 atopic subjects from Groups 1-3 had a higher mean percentage of eosinophils in bronchial brush biopsies (mean 0.58 , SEM 0.4 ) compared with the 26 nonatopic subjects (mean 0.15, SEM 0.1), this difference was not statistically significant $(\mathrm{p}=0.06)$.

In the asthmatic patients (Group 2) the percentage of eosinophils in brush biopsies showed a significant negative correlation with levels of $\mathrm{PC} 20$ (fig. 2), ( $\mathrm{r}=-0.67$; $\mathrm{p}<0.003)$. This association was present for the steroiduntreated asthmatic patients (Group 2a), $(r=-0.77 ; p<0.02)$ but not for the steroid treated asthmatics (Group 2b), $(r=0.14$; NS).

\section{Correlations between bronchial brush biopsies and inflam- matory markers}

The percentage of eosinophils in brush biopsies for the steroid-untreated asthmatic patients (Group 2a) showed a high correlation with bronchial lavage levels of ECP $(\mathrm{r}=0.73 ; \mathrm{p}<0.01)$ (fig. 3$)$ : a weaker correlation was found

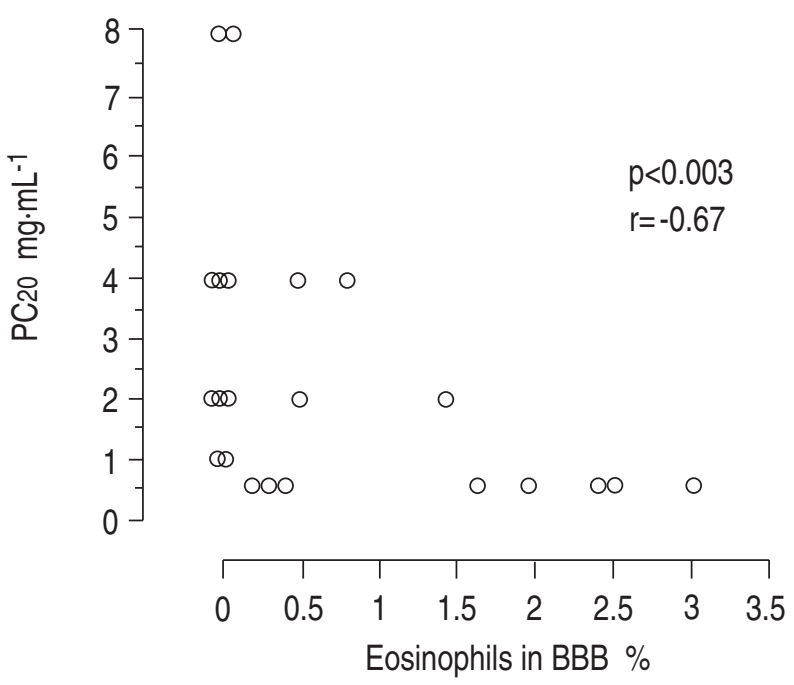

Fig. 2. - Correlation between level of $\mathrm{PC} 20$ and eosinophils in bronchial brush biopsies (BBB) in the asthmatic patients. Spearman's rank correlation test. $\mathrm{PC} 20$ : provocative concentration of methacholine causing a $20 \%$ fall in forced expiratory volume in one second. when all subjects in the study were analysed $(r=0.31$; $\mathrm{p}<0.05$ ).

Weak correlations were found for the percentage of neutrophils with bronchial lavage levels of MPO $(\mathrm{r}=0.33$; $\mathrm{p}<0.05)$ and IL-8 $(\mathrm{r}=0.39 ; \mathrm{p}<0.01)$ when all subjects were analysed. The percentage of mononuclear cells and macrophages did not correlate significantly with markers in bronchial lavage (data not shown).

No significant correlations were found for the percentage of inflammatory cells in bronchial brush biopsies and the levels of inflammatory markers in serum.

\section{Inflammatory markers in bronchial lavage and in serum}

The asthmatic patients not given inhaled steroid therapy (Group 2a) had significantly higher mean bronchial lavage levels of ECP $(p<0.02)$ and hyaluronan $(p<0.002)$ compared with the controls (table 3 ): they also had significantly higher serum levels of ECP $(\mathrm{p}<0.05)$, (table 4).

The asthmatic patients with regular inhaled steroid therapy (Group 2b) had significantly higher mean bronchial lavage levels of ECP $(p<0.02)$ and hyaluronan $(p<0.05)$ compared with the healthy controls (table 3 ). Their serum levels, however, did not differ (table 4).

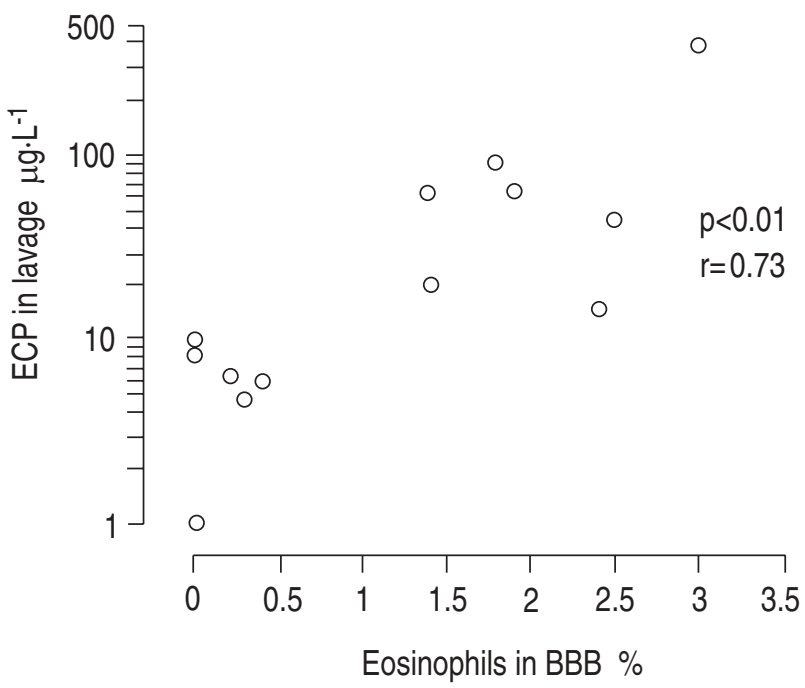

Fig. 3. - Correlation between ECP (logarithmic scale) in bronchial lavage fluid and eosinophils in bronchial brush biopsies (BBB) in steroid-untreated asthmatic patients. Spearman's rank correlation test. ECP: eosinophils cationic protein. 
Table 3. - Small volume bronchial lavage levels of inflammatory cell markers in each subject group

\begin{tabular}{|c|c|c|c|c|c|c|}
\hline Group & & $\begin{array}{c}\mathrm{ECP} \\
\mu \mathrm{g} \cdot \mathrm{L}^{-1}\end{array}$ & $\begin{array}{c}\mathrm{MPO} \\
\mu \mathrm{g} \cdot \mathrm{L}^{-1}\end{array}$ & $\begin{array}{c}\mathrm{HA} \\
\mu \mathrm{g} \cdot \mathrm{L}^{-1}\end{array}$ & $\begin{array}{c}\mathrm{IL}-8 \\
\mathrm{ng} \cdot \mathrm{L}^{-1}\end{array}$ & $\begin{array}{c}\text { Tryptase } \\
\mathrm{U} \cdot \mathrm{L}^{-1}\end{array}$ \\
\hline 1. & Healthy controls & $\begin{array}{c}3.8 \\
(0-34)\end{array}$ & $\begin{array}{c}120 \\
(0-3147)\end{array}$ & $\begin{array}{c}10 \\
(0-599)\end{array}$ & $\begin{array}{c}167 \\
(48-6320)\end{array}$ & $\begin{array}{c}2.9 \\
(0-20)\end{array}$ \\
\hline $2 \mathrm{a}$. & Asthma without inhaled steroids & $\begin{array}{c}10.0^{*} \\
(0-318)\end{array}$ & $\begin{array}{c}85 \\
(30-1345)\end{array}$ & $\begin{array}{c}46 * * \\
(12-102)\end{array}$ & $\begin{array}{c}200 \\
(54-955)\end{array}$ & $\begin{array}{c}4.4 \\
(0-8.2)\end{array}$ \\
\hline $2 b$. & Asthma with inhaled steroids & $\begin{array}{c}11.0^{*} \\
(2.8-96)\end{array}$ & $\begin{array}{c}128 \\
(10-452)\end{array}$ & $\begin{array}{c}32^{*} \\
(0-116)\end{array}$ & $\begin{array}{c}295 \\
(53-1915)\end{array}$ & $\begin{array}{c}2.3 \\
(0-17.5)\end{array}$ \\
\hline 3. & Chronic bronchitis & $\begin{array}{l}14.1 \\
(0-116)\end{array}$ & $\begin{array}{c}71 \\
(0-3108)\end{array}$ & $\begin{array}{c}23^{*} \\
(14-208)\end{array}$ & $\begin{array}{c}398 \\
(5-23308)\end{array}$ & $\begin{array}{c}1.1 \\
(0-5.8)\end{array}$ \\
\hline
\end{tabular}

Values are presented as median, and range in parenthesis. MPO: myeloperoxidase; HA: hyaluronan; IL-8: interleukin-8. *: $\mathrm{p}<0.05$; **: $\mathrm{p}<0.01$; versus the controls (Mann-Whitney U-test).

Table 4. - Serum levels of inflammatory cell markers in each subject group

\begin{tabular}{llcccc}
\hline Groups & & $\mathrm{ECP}$ & $\mathrm{MPO}$ & $\mathrm{HA}$ & $\mathrm{IL}-8$ \\
& & $\mu \mathrm{g} \cdot \mathrm{L}^{-1}$ & $\mu \mathrm{g} \cdot \mathrm{L}^{-1}$ & $\mu \mathrm{g} \cdot \mathrm{L}^{-1}$ & $\mathrm{ng} \cdot \mathrm{L}^{-1}$ \\
\hline 1. & Healthy controls & 6.2 & 395 & 24 & 0 \\
& & $(2.1-18.6)$ & $(300-690)$ & $(0-54)$ & $(0-3780)$ \\
2a. & Asthma without inhaled steroids & $10.5^{*}$ & 415 & 11 & 0 \\
& & $(2.3-41.0)$ & $(270-610)$ & $(0-47)$ & $(0-137)$ \\
2b. & Asthma with inhaled steroids & 7.8 & 405 & 20 & 0 \\
& & $(4.1-14.0)$ & $(240-515)$ & $(0-51)$ & $(0-962)$ \\
3. & Chronic bronchitis & 9.8 & 345 & 29 & 0 \\
& & $(4.1-24.1)$ & $(270-860)$ & $(0-186)$ & $(0-436)$ \\
\hline
\end{tabular}

Values are presented as median, and range in parenthesis. *: $\mathrm{p}<0.05$ versus the controls (Mann-Whitney U-test). For definitions see legends to table 3 .

The mean levels of MPO, IL-8 and tryptase in bronchial lavage and in serum were similar between the asthmatic patients (Group 2) and the healthy controls (tables 3 and 4).

The subjects with atopy $(n=23)$ had significantly higher mean bronchial lavage levels of ECP $\left(47.5 \mu \mathrm{g} \cdot \mathrm{L}^{-1}\right)$ than those without atopy $\left(15.5 \mu \mathrm{g} \cdot \mathrm{L}^{-1}\right),(\mathrm{p}<0.05)$, but their serum ECP levels did not differ significantly. The bronchial ECP levels correlated significantly with the ECP serum levels $(r=0.46 ; p<0.05)$ in the atopic patients (data not shown).

The bronchitic patients (Group 3) had a significantly higher mean bronchial lavage level of hyaluronan $(\mathrm{p}<0.05)$ than the controls (table 3 ). The mean levels of ECP, MPO, IL- 8 and tryptase in bronchial lavage and in serum were not significantly different between the bronchitis patients and the healthy controls (tables 3 and 4).

The levels of tryptase in serum were all below the level of detection (data not shown).

Highly significant correlations were found between the bronchial lavage levels of ECP and hyaluronan $(r=0.68$; $\mathrm{p}<0.001$, Spearman's rank test), and between the bronchial lavage levels of ECP and IL-8 $(r=0.74 ; \mathrm{p}<0.001)$. Also, bronchial lavage hyaluronan correlated significantly with age $(r=0.55 ; \mathrm{p}<0.01)$.

No significant correlations were found between the levels of inflammatory markers and the clinically measured parameters of FEV1, PC20, duration of symptoms or age (except for hyaluronan, as shown above).

\section{Discussion}

Recently, we presented standardized bronchial brushings as a reproducible and relatively simple technique to study airway epithelial cells morphologically in airway disease [1]. Since then, others have found the method useful both for morphological [2] and functional [3, 4] studies of airway cells, including culturing of epithelial cells [28]. In the present study, we used fibreoptic bronchoscopy and the BBB method to study epithelial inflammatory cells in the two inflammatory airway diseases, bronchial asthma and chronic bronchitis. The degree of activation of bronchial inflammatory cells was evaluated indirectly by measurement of cell activation markers in small volume bronchial lavage fluid, a method known to give samples representative of the large airways [29-31]. Bronchial lavage can be performed with the bronchoscope in a wedged [29, 30] or unwedged position [31], and we chose the latter to further minimize possible contamination from the alveolar space. We found that the BBB method was well-tolerated, and gave both intelligible and credible results.

An increased percentage of eosinophil granulocytes was found in the brush biopsies from the steroid-untreated asthmatic patients in comparison with the other groups. The single subject with high eosinophil percentage among the controls was an atopic, who developed asthma within 1 year after the study. These findings are in accordance with results from studies using bronchial biopsies obtained by forceps to investigate the eosinophilic airway inflammation of asthma [5-9]. In addition, the BBB method gives results related to the clinical state of asthma shown by the significant negative correlation for the percentage of eosinophils with the levels of PC20 for the asthmatic patients in the study. This reflects the known relationship between bronchial eosinophilic inflammation and degree of airway reactivity in asthma [32, 33]. Our results are comparable to those of GiBson et al. [2], who reported that a group of steroid-untreated asthmatics 
had eosinophil values between 0.2 and $6.7 \%$ in bronchial brush biopsies, whereas the nonatopic controls had none. However, their subject groups were smaller (23 subjects in four groups), and the differences reported were not statistically significant.

The cytological findings in the BBB method appear to be associated with airway inflammatory cell activity. A significant correlation between the percentage of eosinophils in brush biopsies and ECP levels in bronchial lavage indicates that the $\mathrm{BBB}$ method reflects the degree of eosinophil granulocyte activation measured as ECP [10]. The correlation was especially convincing for the steroiduntreated asthmatic group (fig. 3). The percentage of neutrophils in brush biopsies was found to correlate significantly with MPO, a marker of activated neutrophil granulocytes [34], and the cytokine IL-8, which has a known chemotactic effect on neutrophil granulocytes [32].

However, these last two correlations were weak, and of uncertain clinical relevance. Our results indicate that a quantitative analysis of eosinophils, and possibly neutrophils, in BBB could be of use when studying bronchial changes in asthma as well as other inflammatory airway diseases, e.g. chronic bronchitis as well as chronic obstructive pulmonary disease, where neutrophil inflammation is pronounced $[19,35]$.

As expected, the steroid-untreated asthmatic patients in the study had increased levels of ECP both in small volume bronchial lavage and in serum as compared with the healthy controls. The asthmatic patients given medication in the form of regular steroid inhalation had a significantly increased level of ECP in bronchial lavage, but not in serum. This is in agreement with other reports, reflecting the greater eosinophil activity in the asthmatic patients not given treatment with steroid inhalation [14, 15]. The levels of tryptase in bronchial lavage were comparable between the groups, probably because all asthmatics were investigated during a stable phase in their disease and the bronchoscopies were performed outside the pollen season. In agreement with the findings by LINDEN et al. [20], the median bronchial lavage ECP levels were highest for our patients with nonobstructive chronic bronchitis, but this value did not differ significantly from the other groups due to a large spread in data and small number of subjects. LACOSTE et al. [36] reported increased eosinophils and low levels of ECP in patients with chronic bronchitis, but they analysed BAL fluid, and the changes were significant only for the obstructive bronchitic patients. The levels of MPO in our patients were similar to earlier findings [20], but lower than those reported by LACOSTE et al. [36] in BAL fluid. It is possible that the investigation of bronchitic subjects in whom there is an obstructive component and/or recurrent infectious exacerbations could yield different results than in our nonobstructive and noninfected chronic bronchitis patients [35].

It appears that the lavage method can provide an advantage over bronchial biopsies by reflecting activation of cells normally not easy to quantitate in biopsies, e.g. hyaluronan from activated fibroblasts. The increased levels of hyaluronan found in all the patient groups in the present study are, however, difficult to interpret. Hypothetically, it could reflect the process of subepithelial fibrosis leading to a thickening of the reticular basement membrane known to be present in asthma $[5,6]$. It could also reflect a nonspecific inflammation present both in asthmatic and bronchitic patients, as indicated by the significant correlations for hyaluronan with both age and ECP.

To conclude, our results indicate that the bronchial brush biopsy method gives results which relate to the degree of inflammatory activity and disease severity in asthma. The method yields additional information about the superficial bronchial epithelial changes in inflammatory airways disease. It can possibly be of clinical value in the investigation of cases with unexplainable cough or dyspnoea, where an increased finding of eosinophils would indicate latent asthmatic disease.

Acknowledgements: The writers are grateful for the generous support from The Swedish Heart and Lung Foundation, the Swedish Society for Medicine, and the Medical Society of Göteborg that made this study possible. Special thanks to research nurse B. Balder for help in the recruitment of the asthmatic patients, and to I. Jones for performing the IL-8 determinations.

\section{References}

1. Riise GC, Larsson S, Andersson BA. A bronchoscopic brush biopsy study of large airway mucosal pathology in smokers with chronic bronchitis and in healthy nonsmokers. Eur Respir J 1992; 5: 382-386.

2. Gibson PG, Allen CJ, Yang JP, et al Intraepithelial mast cells in allergic and nonallergic asthma: assessment using bronchial brushings. Am Rev Respir Dis 1993; 148: 80-86.

3. Campbell AM, Chanez P, Vignola AM, et al. Functional characteristics of bronchial epithelium obtained by brushing from asthmatic and normal subjects. Am Rev Respir Dis 1993; 147: 529-534.

4. Vignola AM, Campbell AM, Chanez P, et al. HLA-DR and ICAM-1 expression on bronchial epithelial cells in asthma and chronic bronchitis. Am Rev Respir Dis 1993; 148: 689-694.

5. Azzawi M, Bradley B, Jeffery PK, et al. Identification of activated T-lymphocytes and eosinophils in bronchial biopsies in stable atopic asthma. Am Rev Respir Dis 1990; 142: 1407-1413.

6. Djukanovic R, Lai CK, Wilson JW, et al. Bronchial mucosal manifestations of atopy: a comparison of markers of inflammation between atopic asthmatics, atopic nonasthmatics and healthy controls. Eur Respir J 1992; 5: 538-544.

7. Ollerenshaw SL, Woolcock AJ. Characteristics of the inflammation in biopsies from large airways of subjects with asthma and subjects with chronic airflow limitation. Am Rev Respir Dis 1992; 145: 922-927.

8. Laitinen LA, Laitinen A, Haahtela T. Airway mucosal inflammation even in patients with newly diagnosed asthma. Am Rev Respir Dis 1993; 147: 697-704.

9. Holgate $\mathrm{S}$. Mediator and cytokine mechanisms in asthma. Thorax 1993; 48: 103-109.

10. Bousquet J, Chanez P, Lacoste JY, et al. Eosinophilic inflammation in asthma. N Engl J Med 1990; 323: 1033-1039.

11. Wenzel SE, Fowler AA, Schwartz LB. Activation of pulmonary mast cells by bronchoalveolar allergen challenge. Am Rev Respir Dis 1988; 137: 1002-1008.

12. Bousquet J, Chanez P, Lacoste JY, et al. Indirect evidence of bronchial inflammation assessed by titration of inflammatory mediators in BAL fluid of patients with asthma. J Allergy Clin Immunol 1991; 88: 649-660. 
13. Lundgren R, Söderberg M, Hörstedt P, Stenling R. Morphological studies of bronchial mucosal biopsies from asthmatics before and after 10 years of treatment with inhaled steroids. Eur Respir J 1988; 1: 883-889.

14. Ädelroth E, Rosenhall L, Johansson S-Å, Linden M, Venge P. Inflammatory cells and eosinophilic activity in asthmatics investigated by bronchoalveolar lavage. Am Rev Respir Dis 1990; 142: 91-99.

15. Laitinen LA, Laitinen A, Haahtela T. A comparative study of the effects of an inhaled corticosteroid, budesonide, and a beta 2 -agonist, terbutaline, on airway inflammation in newly diagnosed asthma: a randomized, double-blind, parallel-group controlled trial. J Allergy Clin Immunol 1992; 90: 32-42.

16. Mullen BJ, Wright JL, Wiggs BR, Paré PD, Hogg JC. Reassessment of inflammation of airways in chronic bronchitis. BMJ 1985; 291: 1235-1239.

17. Saetta M, Di SA, Maestrelli P, et al. Activated T-lymphocytes and macrophages in bronchial mucosa of subjects with chronic bronchitis. Am Rev Respir Dis 1993; 147: 301-306.

18. Thompson AB, Daughton DM, Robbins R, Ghafouri MA, Oehlerking M, Rennard SI. Intraluminal airway inflammation in chronic bronchitis. Am Rev Respir Dis 1989; 140: $1527-1537$.

19. Spurzem JR, Thompson AB, Daughton DM, Mueller M, Linder J, Rennard SI. Chronic inflammation is associated with an increased proportion of goblet cells recovered by bronchial lavage. Chest 1991; 100: 389-393.

20. Linden M, Rasmussen JB, Piitulainen E, et al. Airway inflammation in smokers with nonobstructive and obstructive chronic bronchitis. Am Rev Respir Dis 1993; 148: 1226-1232.

21. American Thoracic Society. Standards for the diagnosis and care of patients with chronic obstructive pulmonary disease (COPD) and asthma. Am Rev Respir Dis 1987; 136: 225-244.

22. Ahlstedt S, Enander I, Peterson CGB, Lanner A. The clinical assessment of the inflammatory component in asthma with emphasis on the eosinophils. Pract All Immunol 1993; 8: 149-154.

23. Peterson CGB, Jömvall H, Venge P. Purification and characterization of eosinophil cationic protein from normal human eosinophils. Eur J Haematol 1988; 40: 415-423.

24. Venge P, Strömberg A, Braconier JH, Roxin LE, Olsson I. Neutrophil and eosinophil granulocytes in bacterial infection: sequential studies of cellular and serum levels of granule proteins. Br J Haematol 1978; 38: 475-483.
25. Brandt R, Hedlöf E, Asman I, Bucht A, Tengblad A. A convenient radiometric assay for hyaluronan. Acta Otolaryngol 1978; 442: 31-35.

26. Enander I, Matsson $\mathrm{P}$, Nystrand J, et al. A new radioimmunoassay for human mast cell tryptase using monoclonal antibodies. J Immunol Methods 1991; 138: 39-46.

27. Lindley I, Aschaver H, Seifert JM, et al. Synthesis and expression in Escherichia coli of the gene encoding monocyte-derived neutrophil-activating factor: biological equivalence between natural and recombinant neutrophil-activating factor. Proc Natl Acad Sci USA 1988; 85: 9199- 9203.

28. Kelsen SG, Mardini IA, Zhou S, Benovic JL, Higgins NC. A technique to harvest viable tracheobronchial epithelial cells from living human donors. Am J Respir Cell Mol Biol 1992; 7: 66-72.

29. Yasouka S, Nakayama T, Kawano T, et al. Comparison of cell profiles of bronchial and bronchoalveolar lavage fluids between normal subjects and patients with idiopathic pulmonary fibrosis. Tohoku J Exp Med 1985; 146: 33-45.

30. Lam S, Leriche JC, Kijek K, Phillips D. Effect of bronchial lavage volume on cellular and protein recovery. Chest 1985; 88: 856-859.

31. Rennard SI, Ghafouri MO, Thompson AB, et al. Fractional processing of sequential bronchoalveolar lavage to separate bronchial and alveolar samples. Am Rev Respir Dis 1990; 141: 208-217.

32. Boulet L-P, Morin D, Milot J, Turcotte H. Bronchial responsiveness increases after seasonal antigen exposure in nonasthmatic subjects with pollen-induced rhinitis. Ann Allergy 1989; 63: 114-119.

33. Bradley B, Azzawi M, Jacobson M, et al. Eosinophils, T-lymphocytes, mast cells, neutrophils, and macrophages in bronchial biopsy specimens from atopic subjects with asthma: comparison with biopsy specimens from atopic subjects without asthma and normal control subjects and relationship to bronchial hyper-responsiveness. J Allergy Clin Immunol 1991; 88: 661-674.

34. Schmekel B, Karlsson SE, Linden M, Sundström C, Tegner H, Venge P. Myeloperoxidase in human lung lavage. Inflammation 1990; 14: 447-454.

35. Riise GC, Ahlstedt S, Larsson S, et al. Bronchial inflammation in chronic bronchitis assessed by measurement of cell products in bronchial lavage fluid. Thorax 1995; 50: 360-365.

36. Lacoste JY, Bousquet J, Chanez P, et al. Eosinophilic and neutrophilic inflammation in asthma, chronic bronchitis, and chronic obstructive pulmonary disease. $J$ Allergy Clin Immunol 1993; 92: 537-548. 